\title{
The Importance and Efficacy of Posterior Only Instrumentation and Fusion for Severe Idiopathic Scoliosis
}

\author{
Ciddi İdiyopatik Skolyozda Sadece Posteriordan Yapulan Enstrumentasyon \\ ve Füzyonun Etkinliği ve Önemi
}

\author{
Tolga EGE ${ }^{1}$, Serkan BILGIC ${ }^{2}$, Omer ERSEN ${ }^{3}$, Yuksel YURTTAS ${ }^{1}$, Erbil OGUZ ${ }^{1}$, Ali SEHIRLIOGLU ${ }^{1}$, \\ Atilla KAZANCI ${ }^{4}$ \\ ${ }^{1}$ Gulhane Military Medical Academy, Department of Orthopaedics and Traumatology, Ankara, Turkey \\ ${ }^{2}$ Gulhane Military Medical Academy, Department of Emergency and First Aid, Ankara, Turkey \\ ${ }^{3}$ Gulhane Military Medical Academy, Rehabilitation and Recovery Centre, Department of Orthopaedics and Traumatology, Ankara, Turkey \\ ${ }^{4}$ Yenimahalle State Hospital, Department of Neurosurgery, Ankara, Turkey
}

Correspondence address: Tolga EGE / E-mail: tolgaege77@yahoo.com

\begin{abstract}
AIM: In mild and moderate idiopathic scoliosis (IS), posterior only instrumentation and fusion can provide satisfactory reduction. However in severe and rigid curvatures, combined anterior and posterior fusion is generally required. In this study we have aimed to evaluate the efficacy of posterior only instrumentation in severe thoracolumbar scoliosis clinically and radiologically and compare these results with the literature.

MATERIAL and METHODS: In this retrospective study, 29 consecutive patients with severe idiopathic scoliosis who underwent posterior only instrumentation and fusion between March 2003 and February 2011 were included the study. Radiological evaluation was performed with preoperative, postoperative and folllow up standing AP and lateral $x$-rays. Clinical evaluation was made with shoulder balance and trunk shift. RESULTS: Major curve magnitude decreased to $24,1^{\circ}$ and compensatory curve magnitude decreased to $12.20^{\circ}$ at postoperative period. There was no significant difference in sagittal plane angles. Major curve correction rate was $\% 68,65$ in screw only instrumentation and $\% 65$ in hybrid instrumentation.
\end{abstract}

CONCLUSION: Transpedicular screw instrumentation in severe IS is a safe and effective method in proper hands when flexibility of the curve evaluated accurately in preoperative period.

KEYWORDS: Scoliosis, Posterior vertebral fusion, Anterior vertebral fusion

Öz

AMAÇ: Hafif ve orta derecedeki idiyopatik skolyozda yalnızca posteriordan yapılan enstrumentasyon ve füzyon tatmin edici redüksiyon sağlayabilmektedir. Buna rağmen genelde ciddi ve rijid eğriliklerde kombine anterior ve posterior füzyon gerekmektedir. Mevcut çalışmamızın amacı, ciddi torakolomber idiyopatik skolyozda yalnızca posteriordan yapılan enstrumentasyon ve füzyonun etkinliğinin radyolojik ve klinik olarak değerlendirilmesi ve sonuçlarımızın literatürdeki kombine yaklaşım sonuçları ile karşılaştırılmasıdır.

YÖNTEM ve GEREÇLER: Bu çalışmada, Mart 2003 ile Şubat 2011 tarihleri arasında idiopatik ciddi torakolomber skolyoz nedeni ile sadece posterior enstrumentasyon ve füzyon uygulanmış olan 29 hastanın klinik dosya kayıtları ve veri tabanları retrospektif olarak değerlendirildi. Radyolojik değerlendirmede cerrahi öncesi, sonrası ve takiplerde ayakta çekilmiş ön-arka ve yan grafiler kullanıldı. Klinik değerlendirme omuz dengesi ve gövde kayma miktarları ile yapılmıştır.

BULGULAR: Ameliyat sonrası major eğrilik büyüklüğü $24.1^{\prime}$ 'e düşerken kompansatuar eğrilik dereceleri $12.20^{\circ}$ 'e gerilemişti. Sagital planda açılarında anlamlı bir farklılık saptanmadı. Sadece vidadan oluşan enstrumantasyon uygulanan olgulardaki majör eğrilik korreksiyonu \%68,65 iken hibrid enstrumentasyon uygulanan olgularda korreksiyon miktarı \% 65 olarak bulundu ve iki sistem arasında istatistiksel olarak anlamlı bir fark saptanmadı.

SONUÇ: Ciddi idiyopatik skolyoz korreksiyonunda transpediküler vida uygulaması tecrübeli ellerde yapıldığında ve yine eğriliğin rijiditesi preoperatif olarak uygun bir biçimde değerlendirildiğinde oldukça güvenilir ve etkin bir yöntemdir.

ANAHTAR SÖZCÜKLER: Skolyoz, Posterior vertebral füzyon, Anterior vertebral füzyon 


\section{INTRODUCTION}

In mild and moderate idiopathic scoliosis posterior only instrumentation and fusion can provide satisfactory reduction. However in severe and rigid curvatures, combined anterior and posterior fusion is generally required $(8,13)$.

Disadvantages of anterior procedures are longer surgery and anesthesia times and alterations of pulmonary functions $(2,11)$. After developments in modern posterior instrumentation techniques, severe thoracolumbar curvatures can be reduced by posterior only instrumentation and fusion $(2,13,19)$. With modern posterior instruments stabilizing three columns of vertebrae, shorter fusion levels could be adequate for reduction and the requirement of anterior release and fusion is decreased. Some authors reports that posterior only instrumentation and fusion have similar correction amounts compared with combined procedures even in severe thoracic scoliosis. In several studies reported correction rates are $53,6 \%$ in hook only constructs (9), $54 \%$ in hybrid constructs (2), $67-68 \%$ in screw only constructs $(6,16)$. Beside this, although most important disadvantage of transpedicular screws is neurological complications, most authors showed that transpedicular screw implantation did not increased the neurological complication risk $(15,19)$.

In this study we have aimed to evaluate the efficacy of posterior only instrumentation in severe thoracolumbar scoliosis clinically and radiologically and compare these results with the literature.

\section{MATERIAL and METHODS}

In this retrospective study, 29 consecutive patients with severe idiopathic scoliosis who were underwent posterior only instrumentation and fusion between March 2003 and February 2011 in our clinic were included the study. Patient's records were evaluated from the clinic database. Inclusion criteria were: Severe idiopathic scoliosis (major curve's cobb angle $>60^{\circ}$ ), age between 10-30, one stage posterior only surgery with modern 3.th generation instrumentation and minimum 1 year follow up after surgery. Patients who had brace treatment before the surgery were excluded from the study. Radiological evaluation was performed with preoperative, postoperative and follow up standing AP and lateral $\mathrm{x}$-rays. Assessment of major and compensatory coronal and sagittal curve magnitudes, apical rotation, number of instrumented and fused segments were evaluated on the same radiographs. Flexibilty of the curves were evaluated with preoperative bending $\mathrm{x}$-rays and traction $\mathrm{x}$-rays under general anesthesia. Clinical evaluation was made with shoulder balance and trunk shift.

\section{Surgical procedure:}

All patients were preoperatively evaluated with MRI for intra spinal anomalies. All surgical procedures were performed under continuous SSEP monitorization. However, for suspicious SSEP results the wake-up test was used. Exposure was performed from spinous processes to transvers processes bilaterally throughout the segments fusion planned. Pedicle screws were placed with the free hand technique under fluoroscopic control. Before reduction, posterior release was performed with facet joint resection and interspinoussupraspinous ligament resection. In fusion planned area, the spinous processes were resected, peeled off from soft tissues and used for grafting with demineralized bone matrix.

After screw placement, de-rotation, distraction and compression maneuvers were performed. After decortication of laminas, the wound was closed. Total blood loss, and surgery time were recorded from the patient data. All patients were mobilized on postoperative second day with a soft spinal brace and brace was continued 3 months. Postoperative follow up was done on postoperative 1,3 , and 6 months and then once a year.

\section{RESULTS}

The mean age was 14.6 years (12-28 years) at surgery time. 26 of 29 patients were female. Average major curve magnitude was 71 degrees $\left(60^{\circ}-103^{\circ}\right)$ and average compensatory curve magnitude was $39.8\left(5^{\circ}-72^{\circ}\right)$ degrees. All patients had shoulder imbalance with average of $5^{0}\left(3^{0}-9^{0}\right)$ clavicle angle. On preoperative bending and traction $\mathrm{x}$-rays, average correction rate was $28.8 \%$ in major curve and $66.33 \%$ in compensatory curves. Number of levels fused was 11,7 (714 levels) and number of instrumented levels was 10.6 (5-14 levels ) averagely. While all pedicle screw instrumentation was used in 10 cases, hybrid instrumentation (hooks and pedicle screws) was used in 19 cases. Major curve magnitude decreased to $24.1^{\circ}\left(14^{\circ}-50^{\circ}\right)$ and compensatory curve magnitude decreased to $12.20^{\circ}\left(0^{\circ}-30^{\circ}\right)$ at postoperative period. There was no significant difference in sagittal plane angles. Average correction rate was $66,5 \%$ in major curve and $69,72 \%$ in compensatory curve. Major curve correction rate was $68,65 \%$ in screw only instrumentation and $65 \%$ in hybrid instrumentation averagely. Average postoperative blood loss was $1771 \mathrm{ml}$ (1230-2450 $\mathrm{ml}$ ) and average surgery time was 5 hours and 12 minutes (4-7 hours). Average follow up period was 26 months (12-78). Correction loss during follow up was $2.9^{\circ}$ in major curves and $1.8^{\circ}$ in compensatory curves. Shoulder imbalance decreased to $2^{\circ}\left(0^{\circ}-3^{\circ}\right)$ clavicle angle. See (Table I), (Figure $1 \mathrm{~A}-\mathrm{C}$ ). In three cases during SSEP monitorization, amplitudes were decreased but no neurologic deficit was seen with wake up test. On postoperative period no neurological complications were seen. 3 patients had superficial infections and successfully treated with oral antibiotherapy. 1 patient have had deep infection and treated with debridement and antibiotherapy.

\section{DISCUSSION}

Development of third generation Cotrel-Dubousset (CD) instrumentation system had revealed the segmental fixation concept and correction rates increased over the Harrington system from $18 \%$ to $40 \%$ even $68 \%(8,14,17)$. Initially the CD system composed of hooks and rods, so it didn't show a good success in providing sufficient correction for severe 
Table I: Deformity Correction Parameters

\begin{tabular}{|c|c|c|c|}
\hline & Preoperative & Postoperative & Follow-up \\
\hline Major Curve & $71^{0}\left(60^{0}-103^{\circ}\right)$ & $24.1^{0}\left(14^{0}-50^{\circ}\right)$ & $27^{0}\left(15^{0}-50^{0}\right)$ \\
\hline Flexibility & $\% 28.8$ & ------ & ------ \\
\hline Compensatory Curve & $39.8^{0}\left(5^{0}-72^{0}\right)$ & $12.20^{\circ}\left(0^{0}-30^{\circ}\right)$ & $14^{0}\left(0^{0}-32^{0}\right)$ \\
\hline Shoulder Imbalance & $5^{0}\left(3^{0}-9^{0}\right)$ & $2^{0}\left(0^{0}-3^{0}\right)$ & $2^{0}\left(0^{0}-3^{0}\right)$ \\
\hline Sagittal deformity & $27.9^{0}\left(0^{0}-44^{0}\right)$ & $29.69^{\circ}\left(18^{0}-40^{\circ}\right)$ & $29.80^{\circ}\left(17^{0}-40^{\circ}\right)$ \\
\hline
\end{tabular}

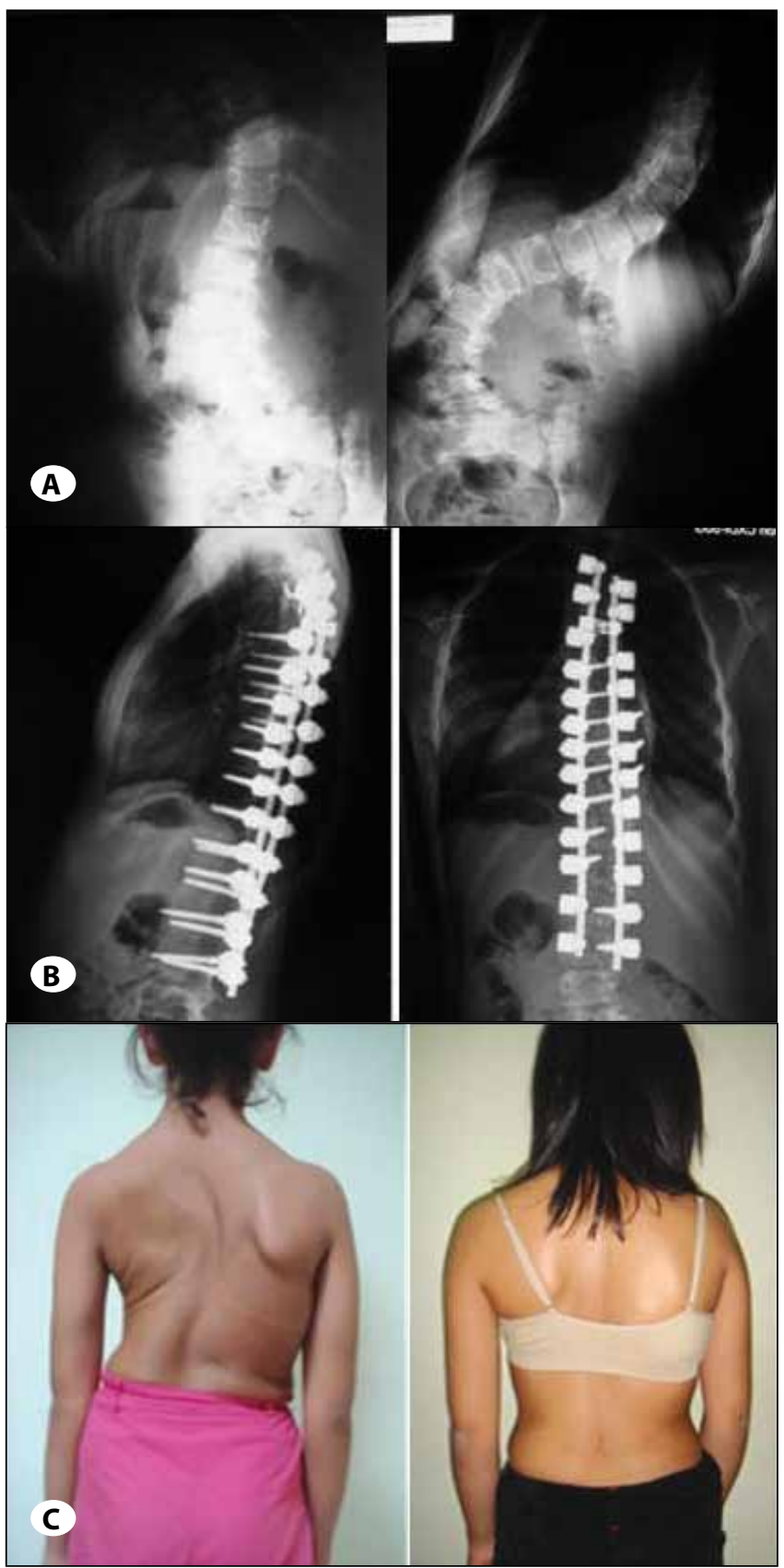

Figure 1: A) Preoperative standing AP, standing lateral and supine side-bending radiographies. B) Postoperative radiographies with wide facet resection, posterior correction with pedicle screws and rod construct, her major curve was reduced to $30^{\circ}$. C)Preoperative and postoperative photographs. and rigid deformities (14-18). After period of time, lumbar transpedicular screw application on CD instrumentation system had provided successful correction of severe scoliosis $(4,19)$. Because transpedicular screws stabilize all 3 columns and provide three plane correction. However, initially transpedicular screws were only used in lumbar region to avoid neurological complications. Because of this, to compensate the insufficiency of correction due to hooks in rigid and severe thoracic curves, thoracotomy and anterior release were added to posterior surgery $(1,24)$. At first, while the classical approach for anterior release was open thoracotomy, the later time in some centers minimally invasive anterior release and fusion with VATS was performed in parallel with technological developments $(1,22,24)$. However the major disadvantages of combined anterior release and posterior instrumentation procedures are: Increase in surgery time, increase in cost of surgery, increase of blood loss and alterations of pulmonary functions $(1,12,20)$. Coe and et al. had analyzed 6334 AIS (adolescent idiopathic scoliosis) cases and found general complication rate $10,1 \%$ with combined procedure and $5.1 \%$ with posterior only instrumentation (7). The most common complication in combined procedure was related to lung. Because thoracotomy affects morphology and biomechanics of thorax wall and pulmonary functions (FEV1 -FVC) (12). Moreover, anterior release affects pulmonary functions even if it is performed with minimally invasive methods (21). Then as a result of these disadvantages, the idea of implementation of the lumbar pedicular screws in the thoracic spine had occurred. However screw application in thoracic region has progressed more slowly than lumbar region because of both thoracic pedicle structure and the risks associated with the development of neurological deficits. In the literature, a variety of methods defined for the application of thoracic transpedicular screws $(3,23)$ and thoracic transpedicular screw complication risk found low $(5,15)$. Kim et al. studied retrospectively 233 AIS patients treated with thoracic transpedicular screws and found no neurologic deficit due to screw instrumentation (15). When the source of such literature, posterior instrumentation and fusion have begun to become a gold standard even in severe scoliotic curves and with posterior only instrumentation, correction rates found similar compared with combined procedures. Dobbs et al. compared the correction results of posterior only and combined procedures in 54 AIS patients and reported similar correction rates (44\%) and similar correction loss at follow up (11). Di Silvestre et al. compared the correction results 
of screw only instrumentation and hybrid instrumentation systems in 52 thoracic scoliosis patients over 80 degrees and reported $52.4 \%$ correction rate in screw only group and $44.52 \%$ in hybrid group (10). In the current study, we have achieved $66.5 \%$ correction rate in major curve and \%69.72 in compensatory curve with posterior only instrumentation and these results were comparable with the literature. In all cases SSEP monitorization was used and no neurological deficit had occurred. Correction loss in last follow up was 3 degrees in major curve and 2 degrees in compensatory curve and this result found comparable with the literature $(2,11,13)$.

In conclusion, transpedicular screw instrumentation in severe idiopathic scoliosis is a safe and effective method in proper hands when flexibility of the curve evaluated accurately in preoperative period. Moreover in thoracolumbar curves between $60-100^{\circ}$, we can achieve proper correction without any anterior release if we use a proper combination of radical posterior release, neurologic monitorization and modern third-generation segmental spinal instrumentation.

\section{REFERENCES}

1. Arlet V: Anterior thoracoscopic spine release in deformity surgery: A meta-analysis and review. Eur Spine J Suppl 1: S17-23 2000

2. Arlet $\mathrm{V}$, Jiang $\mathrm{L}$, Ouellet $\mathrm{J}$ : Is there a need for anterior release for 70-90 degrees masculine thoracic curves in adolescent scoliosis? Eur Spine J 13(8):740-745, 2004

3. Assaker R, Reyns N, Vinchon M, Demondion X, Louis E: Transpedicular screw placement: Image-guided versus lateral-view fluoroscopy: In vitro simulation. Spine (Phila Pa 1976)26(19):2160-2164, 2001

4. Barr SJ, Schuette AM, Emans JB: Lumbar pedicle screws versus hooks. Results in double major curves in adolescent idiopathic scoliosis. Spine (Phila Pa 1976) 22(12):1369-1379, 1997

5. Brown CA, Lenke LG, Bridwell KH, Geideman WM, Hasan SA, Blanke K: Complications of pediatric thoracolumbar and lumbar pedicle screws. Spine(Phila $P a$ 1976) 23(14): 1566-1571, 1998

6. Chang KW: Cantilever bending technique for treatment of large and rigid scoliosis. Spine (Phila Pa 1976) 28(21): 2452-2458, 2003

7. Coe JD, Arlet V, Donaldson W, Berven S, Hanson DS, Mudiyam $\mathrm{R}$, Perra $\mathrm{JH}$, Shaffrey $\mathrm{Cl}$ : Complications in spinal fusion for adolescent idiopathic scoliosis in the new millennium. A report of the Scoliosis Research Society Morbidity and Mortality Committee. Spine (Phila Pa 1976) 31(3):345-349, 2006

8. De Jonge T, Dubousset JF, Illes T: Sagittal plane correction in idiopathic scoliosis. Spine (Phila Pa 1976) 27(7):754-760, 2002

9. De Giorgi G, Stella G, Becchetti S, Martucci G, Miscioscia D: Cotrel-Dubousset instrumentation for the treatment of severe scoliosis. Eur Spine J 8(1):8-15, 1999

10. Di Silvestre M, Bakaloudis G, Lolli F, Vommaro F, Martikos K, Parisini P: Posterior fusion only for thoracic adolescent idiopathic scoliosis of more than 80 degrees: Pedicle screws versus hybrid instrumentation. Eur Spine J 17(10):1336-1349, 2008
11. Dobbs MB, Lenke LG, Kim YJ, Luhmann SJ, Bridwell KH: Anterior/posterior spinal instrumentation versus posterior instrumentation alone for the treatment of adolescent idiopathic scoliotic curves more than 90 degrees. Spine (Phila Pa 1976) 31(20):2386-2391, 2006

12. Graham EJ, Lenke LG, Lowe TG, Betz RR, Bridwell KH, Kong $\mathrm{Y}$, Blanke K: Prospective pulmonary function evaluation following open thoracotomy for anterior spinal fusion in adolescent idiopathic scoliosis. Spine (Phila Pa 1976) 25(18):2319-2325, 2000

13. Hamzaoglu A, Ozturk C, Aydogan M, Tezer M, Aksu N, Bruno $M B$ : Posterior only pedicle screw instrumentation with intraoperative halo-femoral traction in the surgical treatment of severe scoliosis (>100 degrees). Spine (Phila Pa 1976) 33(9):979-983, 2008

14. Helenius I, Remes V, Yrjönen T, Ylikoski M, Schlenzka D, Helenius M, Poussa M: Harrington and Cotrel-Dubousset instrumentation in adolescent idiopathic scoliosis. Long-term functional and radiographic outcomes. J Bone Joint Surg Am 85-A(12):2303-2309, 2003

15. Kim YJ, Lenke LG, Bridwell KH, Cho YS, Riew KD: Free hand pedicle screw placement in the thoracic spine: Is it safe? Spine (Phila Pa 1976) 29(3):333-342; discussion 342, 2004

16. Kuklo TR, Lenke LG, O'Brien MF, Lehman RA, Jr, Polly DW, Jr, Schroeder TM: Accuracy and efficacy of thoracic pedicle screws in curves more than 90 degrees. Spine (Phila Pa 1976) 30(2):222-226, 2005

17. Lenke LG, Bridwell KH, Baldus C, Blanke K, Schoenecker PL: Cotrel-Dubousset instrumentation for adolescent idiopathic scoliosis. J Bone Joint Surg Am 74(7):1056-1067, 1992

18. Lenke LG, Bridwell KH, Blanke K, Baldus C, Weston J: Radiographic results of arthrodesis with Cotrel-Dubousset instrumentation for the treatment of adolescent idiopathic scoliosis. A five to ten-year follow-up study. J Bone Joint Surg Am 80(6):807-814, 1998

19. Luhmann SJ, Lenke LG, Kim YJ, Bridwell KH, Schootman M: Thoracic adolescent idiopathic scoliosis curves between 70 degrees and 100 degrees: Is anterior release necessary? Spine (Phila Pa 1976) 30(18):2061-2067, 2005

20. Niemeyer T, Freeman BJ, Grevitt MP, Webb JK: Anterior thoracoscopic surgery followed by posterior instrumentation and fusion in spinal deformity. Eur Spine J 9(6):499-504, 2000

21. Newton PO, Marks M, Faro F, Betz R, Clements D, Haher T, Lenke L, Lowe T, Merola A, Wenger D: Use of video-assisted thoracoscopic surgery to reduce perioperative morbidity in scoliosis surgery. Spine (Phila Pa 1976) 28(20):S249-254, 2003

22. Newton PO, Shea KG, Granlund KF: Defining the pediatric spinal thoracoscopy learning curve: Sixty-five consecutive cases. Spine (Phila Pa 1976) 25(8):1028-1035, 2000

23. Rampersaud YR, Simon DA, Foley KT: Accuracy requirements for image-guided spinal pedicle screw placement. Spine (Phila Pa 1976) 26(4):352-359, 2001

24. Waisman $M$, Saute $M$ : Thoracoscopic spine release before posterior instrumentation in scoliosis. Clin Orthop Relat Res (336):130-136, 1997 